\title{
G-protein signaling modulator 1 is a modifier of sGC-dependent vascular response
}

\author{
George Britton, Iraida Sharina, Emil Martin \\ From 6th International Conference on cGMP: Generators, Effectors and Therapeutic Implications \\ Erfurt, Germany. 28-30 June 2013
}

\section{Background}

Earlier investigations demonstrated that the activity and function of soluble guanylyl cyclase (sGC) may be modulated by interacting proteins, such as HSP70, HSP90, CCT $\eta$ or PDI. We have also previously demonstrated that G-protein signaling modulator proteins 1 and 2 (GPSM1,2) directly interact with the catalytic region of $\mathrm{sGC}$ and attenuate the response of $\mathrm{sGC}$ to activators in cell lysates.

\section{Results}

In this report, we provide evidence that vascular function of sGC is increased in GPSM1-deficient mice. We found that GPSM1-deficient mice have a lower resting blood pressure than their wild type counterparts. Intraperitoneal injection of sGC stimulator BAY 41-2272 elicited a transient decrease in blood pressure in both strains. However, GPSM1 ${ }^{-1-}$ mice were more sensitive to lower doses of BAY 41-2272, while the decrease in blood pressure was more profound and more sustained than in wild type mice. In ex vivo setting, preconstricted aortic rings from GPSM1 $^{-1-}$ mice were more sensitive to acetylcholine and BAY 41-2272. Western blotting showed similar level of sGC expression in aortas of both strains. H\&E staining of aorta sections showed no obvious morphologic differences between these strains of mice. However, aortas from $\mathrm{GPSM1}^{-1-}$ mice sowed a higher level of cGMP accumulated in response to NO donor DEA-NO than from wild type animals. Unexpectedly, cGMP-degrading activity was also higher in $\mathrm{GPSM}^{-1-}$ mice. These data indicate that, at least in conductive vessels, sGC function is upregulated in the absence of GPSM1. These observations are consistent with previously observed GPSM1-dependent inhibition of sGC in cellular lysates.

\footnotetext{
* Correspondence: emil.martin@uth.tmc.edu

University of Texas Houston Medical School, Department of Internal

Medicine, Division of Cardiology, Houston, Texas, USA
}

\section{Conclusion}

Data presented here clearly indicate that GPSM1 is a modifier of sGC vascular function. Since GPSM1 is known to associate with $\mathrm{G} \alpha$ subunit of heterotrimeric G-proteins, it remains to be determined, if there is any GPSM1mediated cross-talk between sGC function and heterotrimeric G-protein signaling.

Published: 29 August 2013

doi:10.1186/2050-6511-14-S1-P11

Cite this article as: Britton et al: G-protein signaling modulator 1 is a modifier of sGC-dependent vascular response. BMC Pharmacology and Toxicology 2013 14(Suppl 1):P11.
Submit your next manuscript to BioMed Central and take full advantage of:

- Convenient online submission

- Thorough peer review

- No space constraints or color figure charges

- Immediate publication on acceptance

- Inclusion in PubMed, CAS, Scopus and Google Scholar

- Research which is freely available for redistribution
C Biomed Central
C Biomed Central

(C) 2013 Britton et al; licensee BioMed Central Ltd. This is an Open Access article distributed under the terms of the Creative Commons Attribution License (http://creativecommons.org/licenses/by/2.0), which permits unrestricted use, distribution, and reproduction in any medium, provided the original work is properly cited. 